\title{
Online News Coverage of Terrorism: Between Informing the Public and Spreading Fear
}

\author{
Melita Poler Kovačič \\ Nataša Logar ${ }^{* *}$
}

\section{SUMMARY}

To propagate fear, terrorists primarily use social media. Nevertheless, traditional mass media remain very important public sources of information on terrorists' violent acts. Terrorism acts have high news value, so it is pertinent to consider how news media should report them. In the present paper, we first discuss the dilemma between the public's right to be informed about such attacks on the one hand and the value of security on the other. The case of the abduction and execution of Tomislav Salopek, which took place in 2015, was studied. An analysis of 57 news reports on the event from the five most-visited news websites in Slovenia showed that several guidelines that should be followed when covering terrorism were not given enough consideration by the media. Among them were invading privacy of the victim's family and providing only superficial, simplified analysis, with no root cause analysis of the act in question. In the conclusion part, we argue that this was partially caused by the market orientation of the observed websites. In addition, we discuss how such unethical reporting may be rooted in journalists and editors' lack of knowledge about the possible adverse consequences of their actions.

Key words: journalism, terrorism act, right to information, value of security, case study: Tomislav Salopek

\footnotetext{
* Dr. Melita Poler Kovačič, Professor, Faculty of Social Sciences (University of Ljubljana), Slovenia. E-mail: melita.poler-kovacic@fdv.uni-lj.si.

${ }^{* *}$ Dr. Nataša Logar, Assistant Professor, Faculty of Social Sciences

(University of Ljubljana), Slovenia. E-mail: natasa.logar@fdv.uni-lj.si.
} 


\section{Introduction}

The symbiotic relationship between terrorism and the media has often been discussed in scholarly literature (e.g. Rohner \& Frey, 2007; Shoshani \& Slone, 2008; Iqbal, 2015; Rivera, 2016). Media publicity is central to terrorism (Hoffman et al., 2013). In the present globalized world, new and emerging media provide efficient new ways for terrorists to spread their beliefs, intimidate enemies, and recruit fighters (e.g. Farwell, 2014; Burke, 2015). Research shows that terrorists are increasingly using social media as a propaganda tool (Engebrethsen Smith, 2015). New media have empowered terrorists in a number of ways ranging "from planning to financing, recruiting for, executing, and publicizing their activities" (Klopfenstein, 2006: 107).

The possibility of disseminating videos over the Internet enables terrorists to rely less on traditional news media to deliver their messages to widespread audiences (Seib \& Janbek, 2011: ix). However, journalists' coverage of terrorism is not to be neglected. The public still remains very much dependent on information from traditional mass media, which "continue to be a major, perhaps still the major sources of information in this respect" (Nacos, 2016: 112).

Terrorists' posts on social media, such as graphic videos of beheadings filmed by the Islamic State of Iraq and Syria (ISIS), are an easily accessible source for journalists, which has sparked debates about "how much such organisations should be given 'the oxygen of publicity"' (Doward, 2015). A terrorist group makes a video of an execution and sends it out through social media with the intention to be seen and shared. The question is whether those who go along, including the news media, are complicit (Spinner, 2014).

In August 2014, the media centre of ISIS uploaded to YouTube a video showing the beheading of James Foley and a video of the beheading of Steven Joel Sotloff less than two weeks later. Ten days later, it uploaded a video of the beheading of David Haines to Twitter. In February 2015, a video showing the burning of Jordanian pilot Moaz al-Kasasbeh alive was uploaded. The social media sites quickly blocked access to the videos, and relatively few people knew about ISIS' website to which these brutal clips were posted. However, "the world learned almost instantly about the executions via the traditional mass media that in ever more 'breaking news' versions aired alarming details of the unspeakably cruel acts" (Nacos, 2016: 28). In these cases, the news media served "as a magnifying glass" (Ganor, 2005: 236), which intensified the impact of terrorist acts by making them known worldwide.

Terrorists use the media for broad dissemination of their ideology and activities, while the media benefit from reports of terror attacks because such reports increase 
sales and ratings. Nacos (2016: 31$)$ used the term mass-mediated terrorism to describe "the centrality of communication via all kinds of mass media in the calculus of terrorism on the one hand and media gatekeepers' preference for shocking violence on the other hand". Rohner and Frey (2007: 142) described it as "a commoninterest-game, whereby both the media and the terrorists benefit from terrorist incidents and where both parties adjust their actions according to the actions of the other player". Analysis of media attention devoted to terrorist attacks worldwide between 1998 and 2012 revealed that suicide missions had received significantly more coverage, which could explain their increased popularity among terrorist groups; moreover, it was confirmed that media attention for any terror attack is predictive of both the likelihood of another strike in the affected country within seven days' time and a smaller interval before the next attack (Jetter, 2014). The lower interest among Western media for terrorism in developing countries leads terrorists in those countries to commit bloodier terror attacks, for instance, by increasing the number of fatalities and injuries, to obtain the desired media coverage (Rohner \& Frey, 2007). According to Ganor (2005: 231), news coverage of terrorism may impact the different components of an attack, such as the target, duration, timing, and method selected.

These research findings raise the question of how news media should report terrorist threats and guarantee people's right to be informed about matters of public interest, while not giving terrorists an opportunity to disseminate their ideas and cause fear. The central research question of this paper is therefore how Slovenian news media "balance the public's right to know against the ability of militants to exploit news coverage to promote their beliefs" (Rivera, 2016). When reporting on terrorism, journalists are expected to strike a balance between two rights, namely, the right to information (e.g. Article 19 of the Universal Declaration of Human Rights) and the right to security (e.g. Article 3 of the same declaration). Not covering terrorism would undermine exercise of the right to information, while sensationalist news coverage assists terrorism, which is a threat to security. Since security is "a basic value of human relations" (Grizold, 1999: 1), media coverage on terrorism needs to be responsible. The challenge for journalists is not to ignore terrorism "but to provide careful, sensitive reporting that puts extreme and dramatic acts of violence in context without falling into the propaganda trap set by media-savvy terrorists" (White, 2015). To establish how this challenge was met by Slovenian journalists, a case study was conducted. A sample of 57 news reports on the abduction and execution of a Croatian national Tomislav Salopek in Egypt in 2015 was assembled from the five most-visited Slovenian news websites. The reports were analyzed from a linguistic and an ethical perspective, giving us thorough insight into the final results of the reporting process. 


\section{Theoretical Framework}

As mentioned before, the starting-point of our research is the dilemma between the public's right to be informed on matters of public concern and the value of security.

On the one hand, terrorist acts are events with high news value. According to Lewis (2012: 258), terrorism contains several features that make it immediately recognizable as news, such as violence, conflict, drama, and a threat to public safety. News coverage of terrorism in general is in the public interest ${ }^{1}$ because informed public debate about terrorist acts "can lead to forming adequate political responses to it and to preventing others from joining terrorist groups" (Parliamentary Assembly, Council of Europe, 2005). Therefore, it is important that the public is fully informed about terrorist activities. Comprehension of terrorism is essential if the public is to have a voice in governmental responses: "Before surrendering basic rights and values or acceding to bloody military actions, people should understand who the enemy is, what motivates them, how they operate, and what is at stake" (Seib \& Janbek, 2011: ix).

On the other hand, sensationalistic news reporting of terrorist activities ${ }^{2}$ is in the interest of terrorism. Terrorism is a form of politically motivated extreme violence that threatens security (Prezelj, 2016: 167). Nowadays, the most important security threat is no longer war among states, but other threats, including terrorism (Grizold, 2015: 12). Security ${ }^{3}$ has been "the inherent element of existence and actions of an individual, a society or state, and the international system" (Grizold et al., 2012: 15). By serving the terrorists' goals, news media contribute to the goals of those who jeopardize security, which is "one of the oldest values of humanity" (Grizold et al., 2012: 17). For this reason, news coverage of terrorism needs to be thoughtful and responsible, and it needs to consider the essential elements of terrorism and the way terrorism operates to achieve its purpose. As demonstrated by Seib and Janbek (2011: 1), the "principal accomplishment of Al Qaeda on 9/11 was not killing several thousand people, but rather terrifying millions more through the reports and images of the attacks and changing the way many people throughout the world live". Sensationalist news coverage helps terrorist leaders establish their organisation as a well-known brand: "As a result, sensationalist type news fit the aims of terrorists better than a nuanced analysis of terrorism" (Rohner \& Frey, 2007: 132).

Most news organizations did not play complete videos of the ISIS executions in 2014 and 2015, but they publicized the visuals of hostages kneeling next to ISIS killers with the ISIS flag in the picture (Nacos, 2016: 28). However, Fox News posted full raw footage of the Jordanian pilot's execution on its website arguing that "giving readers of FoxNews.com the option to see for themselves the barbarity of ISIS outweighed legitimate concerns about the graphic nature of the video" (John 
Moody in McKelvey, 2015). This decision of Fox News attracted a lot of attention and much criticism. As Nacos (2016: 28) pointed out, ISIS communication experts achieved their immediate goals in this case, namely, "getting the attention of publics and political elites around the globe, shocking and threatening their foes, and impressing supporters and potential recruits".

News coverage of terrorism also raises ethical issues concerning the spreading of stereotypes and prejudice, discrimination, and hate speech. Fears of terrorism are often linked to concerns about immigration, particularly the influx of Muslims (White, 2007: 94-95). Irresponsible news coverage can portray people from other parts of the world as a threat and incite ethnic groups to attack each other (Ward, 2010: 159). For example, a study of the media coverage of 11 terrorist events in the USA (Powell, 2011) showed a pattern of enhancing the culture of fear of Muslims and Islam. Studies (see Ghosh \& Bhui, 2012) confirmed that negative attitudes towards Muslims have been connected to information about terrorist activities involving Arabs/Muslims.

In their coverage of terrorism, news media should refrain from reporting that can contribute to moral panic; instead, they should apply multi-level factual coverage to terrorism and its potential threat to situate it historically and geo-politically and to direct people's efforts towards deconstructing political propaganda (see Rothe \& Muzzatti, 2004: 347). The media should "step up its reporting standards and underline the root causes - not the twisted motives put forward by terrorists" (Rivera, 2016). Furthermore, the media should strive to not over-emphasize and over-cover terrorism at the expense of other global problems, and it should not provide terrorists with massive publicity, which "turns certain terrorists and even terrorist organisations into celebrities" (Nacos, 2016: 99).

In 2005, the Parliamentary Assembly of Council of Europe adopted recommendations pertaining to media and terrorism. Since spreading of public terror, fear, and feelings of chaos "depends largely on the images and messages being carried by media reports about the terrorist acts and threats", the Assembly found it necessary for the public and media to be aware of the fact that terrorists use the media to make the strongest possible impact. The Assembly expressed trust in the ability of journalist "to avoid sensationalist media reports related to terrorism", and invited media professionals

to avoid acting in the interests of terrorists by adding to the feeling of public fear which terrorist acts can create or by offering terrorists a platform for publicity;

to refrain from publishing shocking pictures or disseminating images of terrorist acts which violate the privacy and human dignity of victims or contrib- 
ute to increase the terrorising effect of such acts on the public as well as on the victims and their families;

to avoid aggravating, through their news and comments, the societal tensions underlying terrorism, and in particular to refrain from disseminating any kind of hate speech.

Cohen-Almagor (2005) stressed "an urgent need to develop a set of guidelines for the media when covering terrorism", which should include the following:

The media need to be accountable for the consequences of their coverage.

The media should not jeopardize human life.

The media are advised to co-operate with the government when human lives are at stake $/ . . . /$.

The media should not glorify acts of terror /.../.

The media should refrain from sensational and panicky headlines, from inflammatory catchwords, and from needless repletion of photos from bloody scenes. /.../

Terrorism should be explicitly condemned for its brutality and violent, indiscriminate nature $/ \ldots /$.

The media must not pay or be paid for covering terrorist incidents.

The media are advised not to take upon themselves to mediate between the terrorists and the government. /.../ Journalists are there to cover the event, not to become part of it.

The media are expected to refrain from making dangerous speculations about the terrorists' plans, government response, hostages' messages, and other matters. /.../

Media professionals should have background information about the terrorists they are required to cover. They should do research prior to their coverage.

The media should not broadcast live terrorist incidents that include hostage taking. This is in order not to jeopardize human life and not to impede a government's attempts to rescue the hijacked. This is not to say that the media should not cover such incidents. Rather, there should be a delay of a few minutes during which an experienced editor inspects the coverage and authorizes what should be on air and what should not /.../.

The media are advised not to interview terrorists while the terrorist incident is still in motion. /.../ The media should not impede the negotiations process /.../.

The media should not co-operate with terrorists who stage events /.../.

The media are required to show sensitivity to the victims and to their loved ones. /.../ 
The media are expected not to report details that might harm victims' families.

The area in which the terrorist incident takes place should not be open for anybody who testifies that he or she is a journalist. Only senior and experienced reporters should be allowed in. Junior and inexperienced reporters should undergo a learning process during which they fathom the complexities involved. Adequate training is a necessary precondition.

Ganor (2005: 248) also argued that the media must adopt rules for coverage of terrorism that will "neutralize, or at least minimize, misuse by terrorist organizations". As an example, the author cited the principles recommended in the Shefayim Conference held by the International Policy Institute for Counter-Terrorism in 1997. Among the recommendations were avoiding close-up images of terrorist victims and limiting, as much as possible, repeated broadcast of images of death and destruction from scenes of attack (Ganor, 2005: 238).

In addition to the above-mentioned recommendations pertaining specifically to news coverage of terrorism, responsible news reporting needs to follow other principles of ethical journalism that refer to journalistic work in general, such as verifying information, source attribution, accuracy, publishing corrections, separating facts from opinion or speculation and unconfirmed information, and avoiding the use of secret sources and unconventional methods of information-gathering except in special circumstances.

To sum up, as long as the news media, including their online sites, remain the most important sources of public affairs news for the majority of people, terrorists need the media to further their objectives (Nacos, 2016: 175). Based on a literature review (e.g. Cohen-Almagor, 2005; Parliamentary Assembly, Council of Europe, 2005; Nacos, 2016; Rivera, 2016), several recommendations for news reporting of terrorist activities can be formulated - and should therefore be followed. News media ought to be careful

- when publishing graphic photographs or footage that portray terrorists' violence and may intimidate audiences;

- when reporting on terrorists' threats and acts that may cause fear among audiences;

- when giving media access to terrorists for explaining and justifying their acts;

- to not over-emphasize and over-cover terrorism;

- to not disseminate images or information that violate the privacy and human dignity of victims; 
- to not publish images or information that may affect a victim's family and friends;

- to not publish information that may jeopardize human life;

- to not impede rescue operations;

- to not spread stereotypes that may lead to discrimination and hate speech;

- to not represent violence, that is, terrorist acts and their consequences, out of context and with the intention to attract audiences;

- to avoid sensationalist coverage and to provide the public with analysis that underlines the root causes of terrorism.

In the following section, a case study will indicate whether these recommendations were followed or neglected by Slovenian journalists.

\section{Case Study: News Reporting on the Abduction and Execution of Tomislav Salopek}

\section{Methodology}

The choice of a case study seems appropriate in this research because such studies "comprise more detail, richness, and completeness, and variance - that is, depth for the unit of study" (Flyvbjerg, 2013: 170).

On 22nd July 2015, a terrorism act took place in the outskirts of Cairo. While driving from work in the Egyptian desert, a 31-year-old Croatian citizen Tomislav Salopek was abducted by four members of Sinai ISIS faction. On 5th August, a 75-second video appeared on the Web showing Salopek dressed in an orange jumpsuit and kneeling in the sand with the ISIS flag in the background. A masked militant wielding a knife stood next to him. Salopek read a statement saying that he was abducted by members of the Islamic state and that he would be executed within the next 48 hours unless Egyptian government released all Muslim women imprisoned in Egypt. A rescue operation was launched, but the Egyptian military and police were unable to determine Salopek's whereabouts. On 12th August, the kidnapers published a photograph of a beheaded body, followed by a voice massage claiming they had executed the Croatian hostage.

Tomislav Salopek worked for a French geological company as a topographer, was married, and had two children.

The analytical frame of our analysis consists of 57 news reports on the event. All articles were published by the five most-visited news websites in Slovenia during the 10-day-period between 5th and 14th August 2015. As mentioned, on 5th August, 
the first information about the abduction appeared, whilst the finishing date of our analyses was set to two days after the hostage had been executed. The five news websites were selected based on a MOSS survey (MOSS, 2016):

- 24ur.com (reach percentage in Slovenia: 46.7\%)

- siol.net $(36.9 \%)$

- slovenskenovice.si (30.6\%)

- rtvslo.si $(29.5 \%)$

- zurnal24.si (23.1\%)

The key search term "Tomislav Salopek" yielded different numbers of articles on different websites: 6 on siol.net, 7 on rtvslo.si, 8 on 24ur.com, 10 on zurnal24.si, and 26 on slovenskenovice.si. ${ }^{4}$ To establish how journalists reported the event, we will analyse all of them from two viewpoints - linguistic and ethical - taking visual features such as photographs into account as well. ${ }^{5}$

\section{Results}

The analysis showed that several recommendations for responsible news coverage of terrorist acts were not considered.

\section{Over-covering the Terrorist Act}

A large number of articles covered the Salopek case over the short 10-day period selected for analysis. The extensive media coverage (57 reports) is partly understandable considering that Tomislav Salopek was a Croatian citizen, and Croatia is a neighbouring country of Slovenia; proximity is an influential news-value factor in the selection of events to be covered, as well as drama, bad news, and reference to persons (Harcup, 2004: 30-37).

Yet, the attention devoted to the case seems exaggerated. Day after day, the articles repeated the same information. Even when there was nothing new to report on, the media kept reporting. Such redundant coverage did not contribute to the public being informed but was rather used to retain the attention of audience members, which is the goal of the market-driven journalism practices. The recommendations of not over-covering and over-emphasizing terrorist acts were not respected, particularly by slovenskenovice.si (26 reports in total).

\section{Reporting on the Images of Violence}

When deciding how to report on the visual material representing violence, the analysed websites followed an Aristotelian golden-mean approach. On one hand, they 
chose not to ignore the explicit images of violence, but on the other hand, they did not settle for publishing the most graphic image that was available, that is, the photograph of Salopek's beheaded body. Instead, they tried to find a balance. They all described the contents of the video showing Salopek kneeling in the sand and reading a statement, and they all published a photograph of the kneeling victim, while none of them published the explicit photograph of the body. Siol.net (5th August 2015, 19:19; 7th August 2015, 9:24; 11th August 2015, 9:50) and slovenskenovice. si (5th August 2015, 18:41; 12th August 2015, 17:06) provided a link to the video on YouTube but later it was removed. Reports on 24ur.com included TV news items showing parts of that video, with some clips playing sans sound, but one playing with sound (6th August 2015, 19:35; 7th August 2015, 21:38; 10th August 2015, 18:50). Rtvslo.si also showed a few seconds of the video with sound (8th August 2015, 09:55), while slovenskenovice.si published a blurred photograph of the body (12th August 2015, 13:56).

The photograph of the kneeling victim was published repeatedly on all websites almost on a daily basis, and slovenskenovice.si (8th August 2015, 16:50) even added a photograph of a man allegedly digging his own grave (this had very little to do with the terrorist act in question). Such visual features contributed to dramatization and sensationalism as the essential elements of intimidation, which served the terrorists' goals.

\section{Invading Privacy of the Victim's Family}

All of the analysed websites published information and photographs that violated the privacy of Salopek's family and may have affected the victim's relatives and friends. Sensationalist violations of privacy are against the Code of Slovenian Journalists (DNS \& SNS, 2010), particularly in the case of ordinary people who are not used to media attention (Article 17) and when reporting on family tragedies and situations involving children (Article 19).

Yet, there were differences among the media. While rtvslo.si mostly refrained from invading privacy, with the exception of publishing a photograph of Salopek's children in TV news items (12th August 2015, 13:17; 13th August 2015, 16:08), slovenskenovice.si revealed several pieces of private information, as well as private photographs of the family from Facebook profiles. For example, slovenskenovice.si users could read that Salopek's wife was unemployed (5th August 2015, 19:36), had lost seven kilograms of weight (7th August 2015, 14:14), and would start crying whenever her friends began to talk about her husband (9th August 2015, 19:30). Additionally, many other personal details pertaining to Salopek were revealed by this media outlet, for instance, the love between Salopek and his wife was a step 
towards uniting two villages that had been in long-running dispute and that he was named after his uncle who died in a crash accident (11th August 2015, 7:30). On this website, photographs of Salopek's wife and children (although the children's eyes were covered) were published repeatedly (slovenskenovice.si, 9th August 2015, 19:30; 10th August 2015, 10.45; 11 th August 2015, 7:30; 12th August 2015, 13:56; 12th August 2015, 16:46; 12th August 2015, 17:06; 13th August 2015, 12:16).

In fact, the coverage of Salopek's kidnapping on slovenskenovice.si displayed characteristics typical of tabloid stories (Luthar, 1998; Kalin Golob, 2003; Kalin Golob \& Poler Kovačič, 2005; Conboy, 2006). The selection of words and phrases, inclusion of pseudo-intimate dialogs with readers, vernacular language, repetitions, and melodramatic narration all appealed to readers' emotions. The reporting almost immediately took on the atmosphere of uncertainty, tension, and mistrust in the positive resolution. A constant question of who is to blame, as well as indignations and insinuations, was present. A strong shift into the private life of the victim happened after four days in the article published on 9th August at 19:30. The onward reporting was intonated strongly as Salopek's and his family members' personal tragedy. The follow-up reports were therefore very sentimental in tone and created a feeling of injustice happening to decent, ordinary people.

The other three websites (24ur.com, zurnal24.si and siol.net) revealed some private information but did not emphasize it and kept such invasions of privacy minimal.

When describing how the family members (supposedly) felt, some media outlets resorted to unnamed sources, which was against journalism ethics for at least two reasons: a) it encroached upon the family's privacy even though public interest for such information was not established; b) undisclosed sources are allowed to be used only when the information is in public interest and cannot be obtained in some other way, as stated in the Article 8 of the Code of Slovenian Journalists (DNS \& SNS, 2010). By emphasizing the family's suffering and pain, the media also disseminated fear among the audience, which was in the interest of terrorists. For example:

Meanwhile, Salopek's family is going through the worst time. The kidnapped Croatian is the father of a 2-year-old boy and a 7-year-old girl, who, according to the family, anxiously awaits her father, who was supposed to return home at the end of July. Horrified as well are Salopek's fellow villagers, who pointed out that this is obviously fate which can now come upon anybody who goes out to the world to earn something.

(24ur.com, 8th August 2015, 22:20)

Even though a few news reports regularly identified sources, the decision to interfere with the family's privacy was equally unethical because there was no legitimate public interest for such intrusion. For example: 
"I am heartbroken when I look at the children". / Salopek has two children, a 2-year-old son and a 7-year-old daughter. Neighbours say the little boy still doesn't realise what is happening, while the little girl anxiously expects her father to come home since she knows he was due to return. "When I look at them, I get heartbroken. A stone would cry. Tomislav's father Zlatko is my friend. He and his wife are going through most difficult times in their lives", a family friend Miro Hrastović said. He also told us that Zlatko Salopek had constantly followed the news on the Web, and when he hadn't, he just stared at his beloved son's photograph in silence. "What has he done wrong? He wasn't capable of trampling an ant. As many of our youngsters, he went abroad to earn for the living".

(zurnal24.si, 8th August 2015, 21:06)

Such citations co-constructed the feeling of a horrible personal adversity. ${ }^{6}$ Namely, the media outlets appealed to readers' emotions through either a citation (example above) or a description of the situation from the victim's family or fellow villager's viewpoint.

\section{Disclosing Information about the Abduction and Rescue Operations}

Despite official appeals to not disclose details about the abduction and the subsequent rescue operations, all news sites published available information and speculations such as:

The last trail was registered in Al-Almina town, specifically in the area the main road to Libya passes through, where he might be taken, according to some information. According to Al-Garhy ${ }^{7}$, Egyptian investigators also focused on the sand from the video clip where members of the Islamic state threatened to execute the Croatian...

(24ur.com, 11th August 2015, 9:10)

Thus, the media ignored the recommendation not to publish information that might impede the rescue operations and jeopardise human life.

\section{Disseminating Hate Speech}

Ethically questionable is the decision of siol.net to publish hate speech comments posted under articles on Croatian news websites. For example, consider the following user comment "Let's burn Gornja Maoča!", which was also used as a subtitle for a news article (siol.net, 12th August 2015). Other examples of hate speech are not cited, but according to the journalist, they included appeals to a new crusade and 
to drop a nuclear bomb on Arabic countries. The journalist wrote that such comments "are at the limit of hate speech", yet it could be argued that such comments cross the limits and that they constitute hate speech. Even though the article was supposed to provide readers with information about hate speech comments, hate speech became accessible to a larger number of readers via a journalistic report. According to the Code of Slovenian Journalists (DNS \& SNS, 2010: Article 21), inciting violence, spreading hatred and intolerance, as well as other forms of hate speech, are inadmissible; a journalist should not allow them and should condemn them. The author of the article in question disseminated hate speech without condemning it explicitly, which is against journalism ethics in general, as well as against recommendations for terrorism coverage in particular.

The task of the mass media is not to ignore hate speech, but to actively engage in preventing it by exposing stereotypes and prejudice as the vital force behind hate speech. Among all the analysed news websites, only 24 ur.com published information that the Croatian Islamic Community condemned the abduction, sent an appeal to state and religious institutions in Egypt to help save Salopek, and stressed that terrorist acts are against Islam and the Quran (24ur.com, 8th August 2015, 22:20). ${ }^{9}$ The above-cited news item from siol.net also mentioned that the president of Croatia thanked the Islamic community for their help but did not explain what their help was.

\section{Providing Superficial Analysis}

Instead of providing the public with analysis that underlines the root causes of terrorism, news coverage of the Salopek case was mostly limited to simplified and superficial analysis of possible motives for the kidnapping on Egyptian soil and to speculations about the probable outcome based on past abductions and executions by ISIS. For example, "foreign analysts" were cited to believe that the main motive for the abduction was "destabilization of Egypt, which would happen if international companies and tourists left the country, since this would in the long run lead to an economic breakdown" (24ur.com, 9th August 2015, 23:35). "Some experts" argued that the first motive of the kidnappers was to create a crisis between Egypt and other countries, while the second was to spoil the solemnities at the opening of the renovated Suez Canal (rtvslo.si, 8th August 2015, 15:38). The analysis comprised mostly a few sentences or short paragraphs. The journalists merely reproduced statements of community leaders and statements of unnamed or identified experts, all of which had been obtained by other media (mainly Croatian media) and did not actively search for explanations and expert opinions in Slovenia or abroad.

The analysed media mostly provided "context", which did not have much depth, analysis, or news value. For example, one of the articles published a chronology of 
executions performed by ISIS in 2014 and 2015 (24ur.com, 12th August 2015, 17:26), while another article discussed whether it is safe to travel to Egypt (slovenskenovice.si, 13th August 2015, 18:54). Such coverage could hardly be evaluated as serious journalistic analysis. Instead, it amounted to spreading fear among the audience members, who were now reminded that executions by terrorists take place continually and could eventually happen to anyone. Also noteworthy is the fact that many times, slovenskenovice.si presented confirmed information (viz. confirmation can be established from the very next sentence) as unreliable data (in Slovene, this form often takes shape of words naj bi plus past participle - see underlined parts in the example below): ${ }^{10}$

S Pusićevo naj bi v Egipt odpotovali Salopekova žena in sestra. Skupaj želijo poskusiti vplivati na egiptovske oblasti, naj pomagajo pri reševanju ugrabljenega 31-letnika /.../. (Underlined by authors.)

According to unconfirmed information, together with Vesna Pusić / the Croatian secretary of state for foreign affairs/ Salopek's wife and sister left for Egypt as well. Together, they will try to put pressure on the Egyptian government to help rescue the kidnapped 31-year-old /.../.

(slovenskenovice.si, 6 August 2015, 20:46)

This is considered a misuse of a well-established news reporting syntactic pattern (Korošec, 1998: 33-41; Červ\& Kalin Golob, 2012) and only adds to the exaggerated impression of exclusiveness and dramatization.

\section{Intimidating the Public}

First, findings on the micro level of text analysis, together with the already mentioned excess coverage of the terrorism act in question, revealed a repeated, hence excessive use of nouns and verbs that are clustered semantically around 'violent death'. In this way, lexis such as kidnappers, extremists, members of the Islamic State, terrorists, jihadists, as well as to kidnap, to execute, to kill, or to behead become a part of readers' everyday vocabulary. On slovenskenovice.si, these words were accompanied by adjectives such as violent (death), horrible (footage), brutal (beheading), and terrible (news). Together with nouns such as fear, shock, nightmare, and tragedy, such lexis laid the foundations for the readers to grow a feeling of uncertainty and insecurity and contribute to the comprehension of terrorism as a ubiquitous phenomenon.

On the sentence and paragraph level, the frequent occurrence of antithesis has the same effect. This is also mostly significant for the reporting by slovenskenovice.si. It was characterised by the simultaneous introduction of two opposites, causing an 
Online News Coverage of Terrorism: Between Informing the Public and Spreading Fear

effect of suspense (see examples below); words such as hope, prayer, miracle, destiny, love, to hope, and to rescue complement this suspense as well because they are in strong contrast with fear, shock, and other similar words.

Analysts of the situation are not uniform: some believe that Salopek is a random victim of extremists, while others argue that IS doesn't do anything randomly.

(slovenskenovice.si, 9th August 2015, 11:01)

Ironically, Tomislav went abroad to render his family a better life, yet now, he is waiting for his head to be cut off...

(slovenskenovice.si, 9th August 2015, 19:30)

Tomislav would, in fact, have returned home two days after his kidnapping. Although the family still hopes a miraculous turnaround will happen and that all this is just a nightmare, according to experts cited in foreign media, extremists do not have a single reason to lie about the execution of the unfortunate Croatian.

(slovenskenovice.si, 13th August 2015, 12:11)

Rhetorical questions are another linguistic feature with similar result. Because many headlines and sub-headlines have such a form, incorporating rhetorical questions was obviously a vital strategy for either keeping readers interested or insinuating assertions, for example:

Have jihadists killed Tomislav? (slovenskenovice.si, 8th August 2015, 14: 49)

Can anyone help Tomislav at all? (slovenskenovice.si, 7th August 2015, 17:05)

The intimidation effect intensified after the execution, when the media focused on how the event affected Salopek's family, his acquaintances, Croatian politicians, and society. The media reported that "Croatia is in shock" (slovenskenovice.si, 12th August 2015, 16:46); the Croatian Prime Minister interrupted his holiday and held a press conference (24ur.si, 12th August 2015, 17:26); the president of Croatia called off all her activities for that day (slovenskenovice.si, 12th August 2015, 16:46); and a football club decided to begin the next game of the Croatian championship with a minute of silence to honour Salopek (zurnal24.si, 13th August 2015, 11:21).

The general message delivered by such news coverage was therefore as follows: what happened to Salopek is a tragedy that could happen to anybody. As one of the subtitles said, "Everybody is a potential target of IS" (rtvslo.si, 13th August 2015, 17:12). On slovenskenovice.si, for example, popular idioms, traditional metaphors, and common word plays were used (to find him alive and well, rush to help, hope dies last, he meant a life to her, beloved family, happy return, race against time, 
etc.), making the reporting of this terrorism act equivalent to (tabloid) reporting of car accidents. Such news coverage makes fear of future terrorist acts a constant part of everybody's routine life. Because "the mere threat of terrorist acts can serve the same purpose as an actual terrorist event" (Klopfenstein, 2006: 107), terrorism, therefore, greatly benefits from news reporters not paying attention to recommendations for responsible news coverage.

\section{Discussion and Conclusion}

Terrorism acts attract widespread media attention. To avoid being misused by terrorists, news media should completely avoid sensationalist reporting on terror. Our analysis showed that although the journalists who covered the abduction and execution of Tomislav Salopek were careful not to glorify this act of terrorism (this would undoubtedly be a serious breach of reporting standards), they violated all other recommendations for media coverage on terrorism.

As expected, the most sensationalist reporting was found on slovenskenovice.si, which is the website of the tabloid Slovenske novice, the most-widely read Slovenian daily newspaper (NRB, 2015). Reports by the other four media outlets considered herein also violated the recommendations, but not to the same extent as slovenskenovice.si. Given that the websites 24ur.com, siol.net, and zurnal24.si are commercial media outlets as well, their ethical misconduct was unsurprising. However, rtvslo.si, which is the website of the public broadcaster RTV Slovenija and should therefore be committed to the highest ethical standards, also demonstrated some ethically questionable decisions such as publishing parts of the ISIS video and a photograph of the victim's children.

Sensationalist coverage of terrorism can be explained by the market orientation of the news websites, regardless of whether they are privately or publicly owned. Media outlets compete fiercely to attract greater numbers of users and, thus, higher advertising revenue. According to Nacos (2016: 225), "growing competition in the media market and the trend from hard news to infotainment news has led to more aggressiveness in pursuing the sensational, dramatic, tragic, and frightening aspects of news in general and in the area of terrorism incidents in particular". Slaček Brlek's (2014: 102-103) analysis confirmed that the number of clicks is the most important quantitative resource that influences the work of editors at 24ur.com, siol.net, and rtvslo.si, where the daily editors use this information when deciding the positioning of an article on the website, as well as when selecting titles and photographs. If an editor argues that a particular article is not clicked enough, (s)he moves it to a more exposed position, changes its title/lead, or changes/adds multimedia content (mostly photographs). Salopek's story met the requirements needed 
to gain the attention of media users: it happened to an ordinary citizen in readers' vicinity, was unexpected, tense, emotional, tragic, and could happen to anyone in the future.

In addition to its potential to attract numerous media users, the story fit into the scheme of market-driven journalism because it could be covered without requiring much of journalists' time, effort, and knowledge. Journalists who wrote the analysed articles mostly reproduced content from foreign mass media; their analyses lacked depth and context; there was a lot of repetition, speculation, and unconfirmed information. A similar approach to information-gathering was found in other researches of online journalism in Slovenia. For example, journalists at delo.si and dnevnik.si stated that they rarely actively seek information and hardly ever provide original news; they described themselves as "copy-and-pasters", "translators", "journalists in quotation marks", "news stampers", "robots", and "recyclers" (Vobič, 2013: 100-103). An increasing number of journalists (especially the younger ones) work in precarious, risk-filled employment arrangements - as students, sole proprietors, or on temporary contracts (Vobič, 2015). Media owners and management should recognise the importance of responsible reporting on terrorism, for which well-educated journalists with properly regulated employment status are needed. News coverage of terrorism is not the place for economizing by hiring cheap and under-educated workers, nor is it the place for tabloid journalism intended to gain profits.

Because sensationalist news coverage of terrorist activity is "an asset to the perpetrators at the expense of our society" (Williamson, 2015), more attention should be paid to it both by journalism scholars and practitioners. One of the reasons for unethical reporting may be the journalists and editors' lack of knowledge about the possible consequences of irresponsible coverage. To verify this assumption, further research should be carried out based on ethnographic methods such as observation in newsrooms and interviews with journalists/editors. Nevertheless, the results of our analysis at least indicate that news practitioners should improve their knowledge about issues concerning terrorism, media, and security. Journalism faculties should assume part of the responsibility for educating future journalists on terrorism-related topics. The analysis of journalism programs conducted almost ten years ago in USA, for example, showed that only a few programs had courses focusing specifically on terrorism (Lepre \& Luther, 2007). Because terrorists (can) use sensationalist media coverage to their advantage, media- and terrorism-related courses should become obligatory in journalism university programmes or should at least incorporate terrorism issues into existing syllabuses.

The other part of such responsibility should be assumed by news practitioners themselves, as well as by the managements of media outlets. Given that being a journal- 
ist does not require formal journalism education and those who report on terrorism may not necessarily have passed through the university education system, workshops and training programmes on media coverage of terrorism should be organised. Within professional journalistic organisations, as well as within media organisations, ethical guidelines for news coverage of terrorism should be adopted. Over a decade ago, Cohen-Almagor (2005) suggested guidelines for media coverage of terrorism, stressing that said guidelines "should not be conceived as a step toward licensing. Rather, it is a step to prevent licensing and to increase ethical and professional conduct by reporters and editors". A strong and efficient system of media self-regulation has proven advantageous for journalists and the public because it promotes media quality and protects journalists' independence (Haraszti, 2008: 12). It is our belief that implementing those measures would depower terrorists' abilities to publicize their ideology and activities, and thus contribute to the fight against their destructive and intimidating violence.

\section{ENDNOTES}

1 There is no single definition of public interest. According to the BBC Editorial Guidelines, for example, it includes exposing or detecting crime; exposing significantly anti-social behaviour; exposing corruption or injustice; disclosing significant incompetence or negligence; protecting people's health and safety; preventing people from being misled by some statement or action of an individual or organisation; and disclosing information that assists people to better comprehend or make decisions on matters of public importance.

2 Several cases of irresponsible behaviour on part of the media are analysed in Cohen-Almagor, 2005.

3 For explanations of the different concepts of security, see Grizold and Bučar, 2011.

4 Due to its extensive nature, a bibliographical list of all analysed reports is not included in the paper. However, the list is available from the authors or the editorial office of the journal upon request.

5 We should point out that two of the analysed websites (rtvslo.si and 24ur.com) included news video footages as well (7 in total). Their visual part is of course much richer, but its analysis is nevertheless not included in this paper (with the exception of parts of the original kidnapers' video, see section Reporting on the Images of Violence) given that the focus of the present paper is on the narration of the reporting. Genre and narrative parts of the footages were therefore analysed, but the visuals were mostly left out. Siol.net and slovenskenovice.si also included the original video footage issued by the terrorists on $5^{\text {th }}$ August, but at the time of our analyses, this video was no longer available.

6 See also: 24ur.com, $12^{\text {th }}$ August 2015 (9 $9^{\text {th }}$ paragraph).

7 Mahmood Al-Garhy is an Egyptian journalist.

8 Gornja Maoča is a village in Bosnia that is supposedly a centre of Balkan Wahhabism (Rathfelder, 2010).

9 They also published the appeal of a sister of one of the imprisoned Muslim women to not kill Salopek. A video clip of her statement was published by rtvslo.si as well (8 ${ }^{\text {th }}$ August 2015, 9:55).

10 Since this form gets lost in translation, we have exceptionally cited the Slovenian original as well. 
Online News Coverage of Terrorism: Between Informing the Public and Spreading Fear

\section{REFERENCES}

BBC Editorial Guidelines, http://www.bbc.co.uk/editorialguidelines/guidelines/privacy\#the-public-interest, September 15, 2016.

Burke, J. (2015) "“There is no silver bullet': Isis, al-Qaida and the myths of terrorism”, http://www.theguardian.com/world/2015/aug/19/isis-al-qaida-myths-terrorism-war-mistakes-9-11, August 24, 2016.

Červ, G. \& Kalin Golob, M. (2012) "Sporočanjske vloge in raba dvodelnega členka naj bi z deležnikom na - $l$ v sodobnem tiskanem poročevalstvu”, Slavistična revija, 60 (2), 131-149.

Cohen-Almagor, R. (2005) "Media Coverage of Acts of Terrorism: Troubling Episodes and Suggested Guidelines", Canadian Journal of Communication, 30 (3), 383-409.

Conboy, M. (2006) Tabloid Britain: Constructing a Community through Language. London and New York: Routledge.

DNS \& SNS (2010) “Kodeks novinarjev Slovenije”, http://razsodisce.org/kodeks_ ns_txt.html, September 12, 2016.

Doward, J. (2015) "Media coverage of terrorism 'leads to further violence"”, http:// www.theguardian.com/media/2015/aug/01/media-coverage-terrorism-furtherviolence, August 24, 2016.

Engebrethsen Smith, T. J. (2015) "Islamic State and Social Media: Ethical Challenges and Power Relations", http:/www.idsa.in/idsacomments/IslamicStateandSocialMedia_tjesmith_230115, August 24, 2016.

Farwell, J. P. (2014) “The Media Strategy of ISIS”, Survival, 56 (6), 49-55.

Flyvbjerg, B. (2013) “Case Study”, pp. 169-203. In: N. K. Denzin \& Y. S. Lincoln (Eds.): Strategies of Qualitative Inquiry. Los Angeles etc.: Sage.

Ganor, B. (2005) The Counter-Terrorism Puzzle: A Guide for Decision Makers. New Brunswick and London: Transaction Publishers.

Ghosh, P. \& Bhui, K. (2012) "Perspectives on Security, Terrorism and CounterTerrorism”, Canadian Diversity / Canadian Diversité, 9 (4), 11-14.

Grizold, A. \& Bučar, B. (2011) "Izzivi sodobne varnosti: Od nacionalne in mednarodne do človekove varnosti", Teorija in praksa, 48 (4), 827-851.

Grizold, A. (1999) Evropska varnost. Ljubljana: FDV.

Grizold, A. (2015) "Prologomena", pp. 7-15. In: A. Grizold et al.: Svet na prelomu - Varnostne skupnosti kot odgovor na kompleksno ogrožanje sodobnega sveta. Ljubljana: FDV.

Grizold, A., Mitrevska, M., Wanis-St. John, A., Buchkovski, V. \& Tršar, I. (2012) Conflict Management in the New Security Context: The Case of the Former Yugoslav Republic of Macedonia. Ljubljana: FDV. 
Medij. istraž. (god. 22, br. 2) 2016. (5-26)

Haraszti, M. (2008) The Media Self-Regulation Guidebook.Vienna: OSCE.

Harcup, T. (2004) Journalism: Principles and Practice. London etc.: Sage.

Hoffman, A. M., Shelton, C. \& Cleven, E. (2013) "Press Freedom, Publicity, and the Cross-National Incidence of Transnational Terrorism", Political Research Quarterly, 66 (4), 896-909.

Iqbal, M. Z. (2015) "The Media - Terrorism Symbiosis: A Case Study of Mumbai Attacks, 2008", Asian Journal of Communication, 25 (2), 197-212.

Jetter, M. (2014) “Terrorism and the Media”, IZA Discussion Paper No. 8497, http:// ftp.iza.org/dp8497.pdf, August 24, 2016.

Kalin Golob, M. \& Poler Kovačič, M. (2005) "Med novinarskim stilom in etiko: senzacionalizem brez meja", Družboslovne razprave, XXI (49/50), 289-303.

Kalin Golob, M. (2003) "Stil in novinarski škandal”, Teorija in praksa, 40 (2), 229-244.

Klopfenstein, B. (2006) "Terrorism and the Exploitation of New Media", pp. 107120. In: A. P. Kavoori \& T. Fraley (Eds.): Media, Terrorism, and Theory: A Reader. Lanham etc.: Rowman \& Littlefield Publishers, Inc.

Korošec, T. (1998) Stilistika slovenskega poročevalstva. Ljubljana: Kmečki glas.

Lepre, C. R. \& Luther, C. A. (2007) “The Incorporation of Terrorism Coverage in Academic Journalism Programs", Journalism \& Mass Communication Educator, 61 (4), 361-377.

Lewis, J. (2012) "Terrorism and News Narratives", pp. 257-270. In: D. Freedman \& D. K. Thussu (Eds.): Media \& Terrorism: Global Perspectives. Los Angeles etc.: Sage.

Luthar, B. (1998) Poetika in politika tabloidne kulture. Ljubljana: Znanstveno in publicistično središče.

McKelvey, T. (2015) “Fox News explains why it showed Jordan pilot video", http:// www.bbc.com/news/world-us-canada-31013455, August 26, 2016.

MOSS (2016) "Merjenje obiskanosti spletnih strani”, http://www.moss-soz.si/si/ rezultati_moss/obdobje/default.html?period=201601, July 7, 2016.

Nacos, B. L. (2016) Mass-Mediated Terrorism: Mainstream and Digital Media in Terrorism and Counterterrorism. Lanham etc.: Rowman \& Littlefield Publishers, Inc.

NRB (2015) "Valutni podatki NRB 2015”, September 25, 2016.

Parliamentary Assembly, Council of Europe (2005) "Media and Terrorism. Recommendation 1706", http://assembly.coe.int/nw/xml/XRef/Xref-XML2HTML-en. asp?fileid=17343\&lang=en, July 7, 2016.

Powell, K. A. (2011) "Framing Islam: An Analysis of U.S. Media Coverage of Terrorism since 9/11”, Communication Studies, 62 (1), 90-112. 
Online News Coverage of Terrorism: Between Informing the Public and Spreading Fear

Prezelj, I. (2016) “OZN in boj proti mednarodnemu terorizmu”, Teorija in praksa, 53 (1), 167-183.

Rathfelder, E. (2010) "Bosnien: Razzia in der Hochburg der Islamisten". Die Presse, 2 February, http://diepresse.com/home/politik/aussenpolitik/537079/Bosnien_ Razzia-in-der-Hochburg-der-Islamisten, July 7, 2016.

Rivera, J. D. (2016) “The Symbiotic Relationship between Western Media and Terrorism”, http://www.carnegiecouncil.org/publications/ethics_online/0117/: pf_printable?, August 25, 2016.

Rohner, D. \& Frey, B. S. (2007) "Blood and ink! The common-interest-game between terrorists and the media", Public Choice, 133 (1-2), 129-145.

Rothe, D. \& Muzzatti, S. L. (2004) "Enemies Everywhere: Terrorism, Moral Panic, and US Civil Society", Critical Criminology, 12 (3), 327-350.

Seib, P. \& Janbek, D. M. (2011) Global Terrorism and New Media: The Post-Al Qaeda Generation. London and New York: Routledge.

Shoshani, A. \& Slone, M. (2008) "The Drama of Media Coverage of Terrorism: Emotional and Attitudinal Impact on the Audience", Studies in Conflict \& Terrorism, 31 (7), 627-640.

Slaček Brlek, A. S. (2014) "Kvantifikacija občinstev kot ključni dejavnik odločanja v spletnih uredništvih”, Javnost/The Public, 21 (Supplement), S93-S111.

Spinner, J. (2014) "The Careful Calculations behind Covering ISIS Execution Videos”, http://ajr.org/2014/09/12/media-coverage-journalist-execusion-videos/, August 24, 2016.

The Universal Declaration of Human Rights, http://www.un.org/en/universal-declaration-human-rights/, August 29, 2016.

Vobič, I. (2013) Journalism and the Web: Continuities and Transformations at Slovenian Newspapers. Ljubljana: FDV.

Vobič, I. (2015) “Osiromašenje novinarstva”, Javnost/The Public, 22 (Supplement), S28-S40.

White, A. (2007) “To Tell You the Truth: The Ethical Journalism Initiative”, Brussels: IFJ, http://ethicaljournalisminitiative.org/pdfs/EJI_book_en.pdf, August 25, 2016.

White, A. (2015) "Reporting Terrorism: How Reckless Media Can Make Matters Worse", http://ethicaljournalismnetwork.org/en/contents/reporting-terrorismhow-reckless-media-can-make-matters-worse, August 24, 2016.

Williamson, K. (2015) "Sensationalizing Media \& Terrorism: The Achilles Heel of the American People”, http://www.gnovisjournal.org/2015/03/25/sensationalizing-media-terrorism-the-achilles-heel-of-the-american-people/, July 8, 2016. 


\title{
On-line izvještavanje o terorizmu: Između informiranja javnosti i širenja straha
}

\author{
Melita Poler Kovačič \\ Nataša Logar
}

\section{SAŽETAK}

Za širenje straha teroristi prvenstveno koriste društvene medije. Unatoč tome, tradicionalni masovni mediji ostaju za javnost vrlo bitni izvori informacija o nasilnim radnjama terorista. Teroristički zločini imaju visoku vrijednost u vijestima, stoga je važno razmotriti kako bi ih mediji trebali prenositi. U ovome članku prvo smo raspravili dilemu koju predstavlja pravo javnosti da bude informirana o takvim događajima s jedne strane i vrijednost sigurnosti s druge. Analiziran je slučaj otmice i pogubljenja Tomislava Salopeka u 2015. godini. Analiza 57 novinskih izvještaja o tome događaju, objavljenih na pet najposjećenijih novinskih portala u Sloveniji, pokazala je kako mediji nisu dostatno poštivali nekoliko smjernica koje bi trebalo slijediti prilikom izvještavanja o terorizmu. Među njima su narušavanje privatnosti žrtvine obitelji i pružanje samo površnih, pojednostavljenih analiza, bez analize glavnog uzorka dotičnog događaja. U zaključnom dijelu, tvrdimo kako su navedeni problemi djelomično prouzrokovani tržišnom orijentacijom proučavanih internetskih stranica. Raspravili smo, također, i kako bi takvo neetično izvještavanje moglo biti uzrokovano neznanjem novinara i urednika o mogućim štetnim posljedicama njihovih odluka.

Ključne riječi: novinarstvo, terorizam, pravo na informaciju, vrijednost sigurnosti, studija slučaja: Tomislav Salopek 